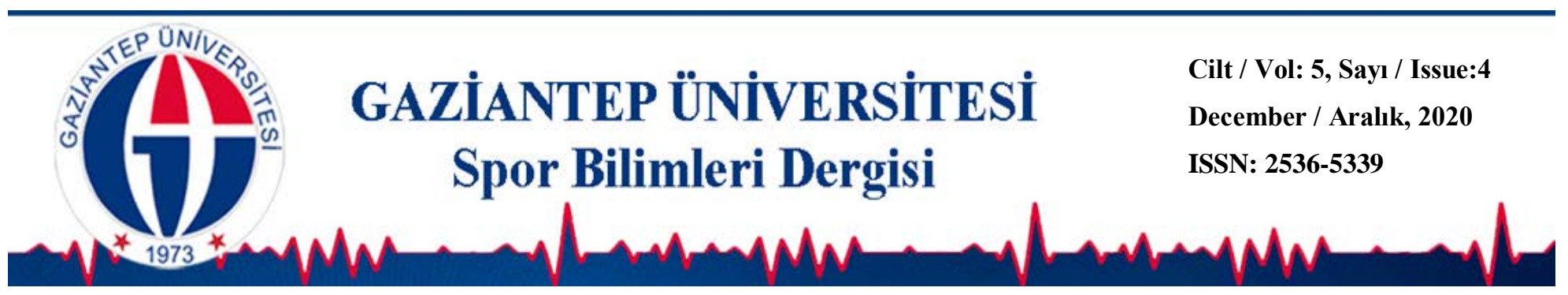

\title{
Effects of Core Exercises on Thyroid Metabolism in Men
}

\author{
Zarife PANCAR ${ }^{1}$ \\ ${ }^{1}$ Gaziantep University, Sport Science Faculty, GAZIANTEP
}

DOI: $10.31680 / g a u n j s s .826057$

Orijinal Makale / OriginalArticle

Geliş Tarihi / Received:14.11.2020

Kabul Tarihi / Accepted: 11.12.2020

Yayın Tarihi / Published: 14.12.2020

\begin{abstract}
The aim of this study is to investigate the effects of 6-week core strength exercises on TSH (thyroid stimulating hormone), $T_{3}$ (triiodothyronine) and $T_{4}$ (thyroxine) levels in men who exercise regularly. A total of 24 healthy volunteers were included in the study with an average age of 20-22 years. Before the study, individuals were randomly divided into two groups as control (n: 12) and core exercise (n: 12) groups. While no application was made to the control group, a program consisting of core exercises suitable for their levels was applied to the core exercise group for 6 weeks, 3 days a week. Blood samples were taken from the forearm veins for analysis of TSH (mlU/L), $\mathrm{T}_{3}(\mathrm{pg} / \mathrm{ml})$ and $\mathrm{T}_{4}(\mathrm{ng} / \mathrm{dl})$ values from all individuals between 09:00 and 10:00 in the morning before and one day after the exercise application. In the analysis of the data obtained, a statistically significant difference was found in the TSH and $\mathrm{T}_{4}$ values of the exercise group in favor of the post-test $(p<0.05)$. In the statistical analysis of the control and experimental groups, a significant difference was found between the groups in favor of the experimental group $(p<0.05)$. At the end of the study, we can say that core strength exercises applied to men cause changes in thyroid metabolism.
\end{abstract}

Keywords: Core strength, thyroid, exercise

\section{Introduction}

Regular physical exercise is known to protect against diseases such as cardiovascular diseases, ischemic heart disease, heart failure, chronic obstructive pulmonary disease and type 2 diabetes (Jolliffe et al. 2001; Boulé et al. 2001). Physical activity has an effect on improving aerobic performance, cardiovascular endurance, muscle strength and flexibility, body composition, as well as reducing anxiety, increasing self-confidence and self-esteem (Aşçı, 2014; Şan et al. 2019).Exercise not only causes anthropometric changes in the human body, but also causes various physiological changes such as hypertrophy, strength gain, hormonal changes (Fary and Kraemer, 1997), and some performance variables such as endurance and strength that can be seen as a result of these changes are factors

\footnotetext{
${ }^{1}$ Sorumlu Yazar: Zarife PANCAR
}

E-mail: z_pancar@hotmail.com 
Pancar, Z. (2020). Effects of Core Exercises on Thyroid Metabolism in Men. Gaziantep Üniversitesi Spor Bilimleri Dergisi, 5(4); 590-597.

affecting sportive success (İnce et al. 2020; Ozan et al. 2020).These changes seen during or after exercise bring along some enzymatic and hormonal adaptations (Hackney and Dobridge, 2009; Ehrman et al. 2018).

The variety of hormones, their effective role in providing hemeostasis, exercise, stress, etc. hormones have become one of the issues that sports scientists have been working on for years and have managed to keep up to date (Özbay et al., 2020; Ince, 2020). The endocrine system can function functionally in almost all tissues of the body.Together with the nervous system, it is classified as one of the two most basic systems of the human body (Ratemess, 2012). The endocrine system helps the body to maintain its normal functions, prepares the body for exercise and various stressful environments, and plays an important role in various adaptations of the body.Thanks to such functions, the endocrine system helps to maintain performance during exercise, to provide chronic adaptation to training in the human body, and consequently to improve exercise and sports performance (Ratemess, 2012). The functions of hormones have been studied on many variables such as different environments, different types and intensities of exercises, different weather temperatures, genders, and different ethnic origins, and are still being studied today (Günay et al., 2018). Based on this information, the aim of this study is to investigate the effects of healthy male individuals undergoing core strength exercises on thyroid metabolism.

\section{Methods}

\section{Subjects}

A total of 24 healthy and volunteer individuals with an average age of 20-22 years participated in the study. The criteria for the individuals to be included in the study were exercising, being healthy, not smoking and volunteering.They were randomly divided into two groups as control (n: 12) and core strength exercise group (n: 12). Control group means; age, $22.50 \pm 3.54$ height, $178 \pm 10.92$ body weight was found to be $77 \pm 8.92$.Averages of the core strength exercise group;age $21.25 \pm 1.66$ height, $175.75 \pm 5.94$ body weight, $77.25 \pm 8.92$ was measured and recorded. Voluntary consent was obtained from all individuals participating in the study. 
Pancar, Z. (2020). Effects of Core Exercises on Thyroid Metabolism in Men. Gaziantep Üniversitesi Spor Bilimleri Dergisi, 5(4); 590-597.

\section{Experimental design}

This study is an experimental study with a control group.No application was applied to the control group for 6 weeks. For the exercise program, they were chosen from among individuals who are members of a private fitness center and who have been exercising regularly for a year, considering their age levels. Exercises were done between 10:00 and 12:00 at the members' entrance time.All individuals were told to avoid vigorous physical activities, except for the application. Age, height and body weight measurements were recorded by informing about the exercise protocol and the study beforehand.

\section{Procedures}

\section{Core Strength Procedure}

A six-week program consisting of seven basic movements including core strength exercises was applied to the individuals participating in the study. Exercise frequency was determined as three days a week. Exercise volume was determined as two sets during the first two weeks and 10 repetitions per set with 10 seconds of rest between each set.For the other two weeks, the exercise volume was two sets and 15 reps per set with 15 seconds of rest between each set.The exercise volume for the last two weeks was three sets and 15 repetitions per set with 15 seconds of rest between each set.Basic movements; it consists of abdominal crunch, vertical leg crunch, jack knife, reverse crunch, superman, plank with alternating arm and leg raise, and plank jack movements.All these core strength exercises were applied in the same way in all sessions. Five minutes of walking or jogging, 2 minutes skipping rope and $5 \mathrm{~min}$ of static stretching for major muscles were practiced to warm-up and cool-down (Özdal, 2016; Özdal et al. 2019; Escamilla et al. 2010).

\section{Biochemical Analysis}

Blood samples were taken from the paerticipants in the resting condition twice before and after 24 hours the study. Venous blood samples were collected from the right arm of the participants into $5 \mathrm{ml}$ at the central laboratory of Gaziantep University Faculty of Medicine between the hours of 09:00 and 10:00 in the morning. Blood samples were collected by a gel biochemistry tube by expert. 


\section{Statistical Analysis}

SPSS 22.0 (SPSS Inc., Chicago, IL, USA) program was used for statistical analysis. Values were represented as mean and standard deviation, and significance was set at 0.05. Kolmogorov-Smirnov test was performed to assess normality, and 2x2 mixed-factor analysis of variance and least significant difference tests were performed to analyze intra- and intergroup differences.

\section{Results}

Statistical analysis of the data obtained in the study is shown in Table 1.The TSH and T4 values of the group that underwent core strength exercises were found to be significant $(1.34 \pm 0.45)$ between the pre-test and the post-test.At the same time, unlike the control group, TSH values were found to be significant $(-0.86 \pm 1.02)$ in favor of the experimental group $(p<0.05)$. No difference was found in the control group $(p>0.05)$.

Table 1.Statistical data of the control and exercise group

\begin{tabular}{clcc}
\hline & & CG. & CTG. \\
& & Mean+SD & Mean+SD \\
\hline TSH & Pre-test & $1.85 \pm 0.98$ & $2.20 \pm 1.10$ \\
(mlU/L) & Post-test & $1.80 \pm 0.52$ & $1.34 \pm 0.45^{\mathbf{A}}$ \\
& Difference & $-0.06 \pm 0.67$ & $-0.86 \pm 1.02^{\mathrm{B}}$ \\
\hline \multirow{2}{*}{ T3 } & Pre-test & $3.55 \pm 0.28$ & $3.35 \pm 0.63$ \\
(pg/ml) & Post-test & $3.64 \pm 0.42$ & $3.63 \pm 0.32$ \\
& Difference & $0.09 \pm 0.42$ & $0.27 \pm 0.61$ \\
\hline \multirow{2}{*}{ T4 } & Pre-test & $1.40 \pm 0.15$ & $1.39 \pm 0.17$ \\
(ng/dl) & Post-test & $1.37 \pm 0.20$ & $1.27 \pm 0.15^{\mathrm{A}}$ \\
& Difference & $-0.03 \pm 0.20$ & $-0.12 \pm 0.16$ \\
\hline
\end{tabular}

CG: control group, CTG: Core training group, SD: standard deviation, A:significant difference between pre- and post-tests, B: significant difference from CG.

\section{Discussion}

This study aimed to examine the effects of core strength exercises on thyroid metabolism in healthy volunteer men.At the end of the study, it was determined that the group that was exercised affected the $\mathrm{TSH}$ and $\mathrm{T}_{4}$ levels among the thyroid values.

$\mathrm{T}_{3}$ and $\mathrm{T}_{4}$ hormones secreted by the thyroid gland play an important role in the regulation and acceleration of the body's metabolic rate. Thyroid hormones $\mathrm{T}_{3}$ and $\mathrm{T}_{4}$ are mostly released in the circulation due to carrier proteins (thyroxine binding globulin, prealbumin and albumin). Since $\mathrm{T}_{4}$ generally has a lifespan of 20 times 
Pancar, Z. (2020). Effects of Core Exercises on Thyroid Metabolism in Men. Gaziantep Üniversitesi Spor Bilimleri Dergisi, 5(4); 590-597.

longer than $\mathrm{T}_{3}$, it is more common in circulation (Gençoğlu and Akkuş, 2020). Thyroid hormones affect and change many metabolic events in the body.Thyroid hormones make it easier for electrolytes to enter the cell by activating the enzyme Na-K + ATP in the cell membrane.Likewise, it increases the entry of amino acids and glucose into the cell.It accelerates oxidative phosphorylation in cell mithecares.In this way, supplies energy to the cell.It increases the activity of RNA by binding to receptors in the cell nucleus (Görpe and Görpe, 1987). Thyroid hormone causes an increase in basal metabolic rate, a decrease in body weight, an increase in blood flow, heart rate and flow, an acceleration of respiration, and stimulation of the central nervous system. The overall effect of thyroid hormones comes from stimulating the structure of many genes (Berne et al. 2008).In our study, the decrease in TSH and $T_{4}$ values of the core exercises group was found to be significant.

According to the results of this decrease, the metabolic demand after exercise increases and it tends to decrease because of the need to rearrange the cellular damage that occurs in a stressful situation in the body such as exercise (Mastorakos and Pavlatou, 2005). High thermogenesis with increased metabolic demand is attempted to be balanced by heat spreading vasodilation.In this case, the metabolic rate and the resulting thermogenesis are regulated by thyroid hormones (Fortunato et al. 2008).In a study conducted, a decrease was found in $T S H, T_{3}$ and $T_{4}$ values of submaximal exercises in sedentary individuals (Akıl et al. 2011). Sultan and Rashed (2009) stated in their study that one-month exercise and diet create differences in thyroid hormones. Teixeira and friends (2017) found in their study that there was no major change in thyroid hormones of the ten-week exercise program. Masaki and friends (2019) found that acute exercise had changes in TSH and $\mathrm{T}_{3}$ levels, and there was no change in $T_{4}$ level. In their study, Çınar and friends (2017) determined that a six-week exercise program and zinc supplement affected the participants' thyroid hormone metabolism positively.

Increased thyroid hormone increases systemic vascular resistance and increases cardiac contractility. $T_{3}$ acts directly and indirectly on human ventricular proteins(Koloğlu and Erdoğan, 2005). It stimulates carbohydrate metabolism.It causes an increase in glucose uptake of cells, an increase in glucose absorption, and an increase in insulin resistance (Chidakel et al. 2005).

In a study conducted; showed that long-term exercises applied to sixteen athletes affect thyroid metabolism (Erdoğan, 2020). Akbulut and his friends (2019), 
Pancar, Z. (2020). Effects of Core Exercises on Thyroid Metabolism in Men. Gaziantep Üniversitesi Spor Bilimleri Dergisi, 5(4); 590-597.

determined that an eight-week exercise program and vitamin E supplementation caused changes in thyroid hormone metabolism. Zarei and friends (2018), observed that chronic exercises increase TSH level and decrease $T_{3}$ and $T_{4}$ levels. In their study, Chicharro and friends (2001), reported that the three-week race period process increased the $\mathrm{T}_{4}$ level and did not change the TSH and $\mathrm{T}_{3}$ levels. In their study, Johannsen and friends (2012), stated that acute troxin and exercise practises had significant changes in thyroid hormones.

As a result, when the findings obtained from the study are evaluated with the literature information, we can say that the core strength exercises applied change the serum thyroid metabolism levels.

\section{References}

Akbulut, T. Çınar, V. \& Erdogan, R. (2019). The Effect of High Intensity Interval Training Applied with Vitamin E Reinforcement on Thyroid Hormone Metabolism. Revista Romaneasca pentru Educatie Multidimensionala. 11(4Sup1): 01-07.

Akıl, M. Kara, E. Biçer, M. Acat, M. (2011). The Effects Of Submaxımal Exercises on the Thyroid Hormonal Metabolism of Sedentary Individuals. Nigde University Journal of Physical Education And Sport Sciences. 5(1):28-33.

Aşçı, H. (2014). Does Physical activity/Exercise make women good? International Gender and Sport Symposium, Abstract Book, Ankara.

Berne, M.R. Levy, N.M. Koeppen M.B. Stanton, B.A.(2008). Fizyoloji, 5.baskı.

Boulé, NG. Haddad, E. Kenny, G.P. Wells, GA. Sigal, RJ. (2001). Effects of exercise on glycemic control and body mass in type 2 diabetes mellitus: a metaanalysis of controlled clinical trials. Jama. 286(10): 1218-27.

Chicharro, J.L. Hoyos, J. Bandrés, F. Terrados, N. Fernández, B. \& Lucía, A. (2001). Thyroid hormone levels during a 3-week professional road cycling competition. Hormone Research in Paediatrics. 56(5-6), 159-164.

Chidakel, A. Mentuccia, D. Celi, F.S. (2005). Peripheral metabolism of thyroid hormone and glucose homeostasis. Thyroi, 5(8): 899-903.

Çınar, V. Akbulut, T. \& Sarikaya, M. (2017). Effect of zinc supplement and weight lifting exercise on thyroid hormone levels. Indian Journal of Physiology and Pharmacology, 61(3), 232-236. 
Pancar, Z. (2020). Effects of Core Exercises on Thyroid Metabolism in Men. Gaziantep Üniversitesi Spor Bilimleri Dergisi, 5(4); 590-597.

Ehrman, J.K. Kerrigan, D. and Keteyian, S. (2018). Advanced Exercise Physiology: Essential Concepts and Applications: Human Kinetics.

Erdoğan, R. (2020). Effects of Endurance workouts on thyroid hormone metabolism and biochemical markers in athletes. Brain. Broad Research in artificial intelligence and neuroscience. 11(3): 136-146.

Escamilla, RF. Lewis, C. Bell, D. Bramblet, G. Daffron, J. Lambert, S. Pecson, A. Imamura R. Paulos L. Andrews JR. (2010). Core muscle activation during Swiss ball and traditional abdominal exercises. J Orthop Sports Phys Ther. 40(5):265-276.

Fortunato, R.S. Ignácio, D.L. Padron, A.S. Peçanha, R. Marassi, M.P. Rosenthal, D. Werneck-de-Castro, J.P. Carvalho, D.P. (2008). The effect of acute exercise session on thyroid hormone economy in rats. J Endocrinol. 198(2): 347-53.

Fry, C. and Kraemer, W.J. (1997). Resistance Exercise Overtraining and Overreaching. Sports Medicine. 23(2):106-129.

Gençoğlu, C. Akkuş, E. (2020). Egzersize Tiroid Hormon Yanıtları. Medical Sciences. 15(3):71-80.

Görpe, A. Görpe, U. (1987). Pratik Endokrinoloji, 2stanbul Üniversitesi, Ermete matbaası Merter-İstanbul.

Günay, M. Şıktar, E. Cicioğlu, İ. et al., (2018). Egzersiz-Antrenman ve Hormonal Uyumlar, Ankara: Gazi Kitabevi.

Hackney, A.C. and Dobridge, J.D. (2009). Thyroid Hormones and the Interrelationship of Cortisol and Prolactin: Influence of Prolonged, Exhaustive Exercise. Endokrynologia Polska, 60(4):252-257.

İnce, İ. (2020). Metabolik Bozukluklara Karşı Egzersiz ile İlişkili Yeni Bir Miyokin: İrisin. Türk Spor Bilimleri Dergisi, 3(1):44-50.

Johannsen, D. L. Galgani, J.E. Johannsen, N.M. Zhang, Z. Covington, J.D.\& Ravussin, E. (2012). Effect of short-term thyroxine administration on energy metabolism and mitochondrial efficiency in humans. PLoS One, 7(7), e40837.

Jolliffe, JA. Rees, K. Taylor, RS. Thompson, D. Oldridge, N. Ebrahim, S. (2001). Exercise-based rehabilitation for coronary heart disease. Cochrane Database of Systematic Reviews. 1(1): 1-65.

Koloğlu, S. Erdoğan, G.(2005). Tiroid: Genel Görüş ve Bilgiler. In: Erdoğan G, editor. Koloğlu Endokrinoloji, Temel ve Klinik, 2. Basım, Nobel Kitabevi, Ankara. 
Masaki, M. Koide, K. Goda, A. Miyazaki, A. Masuyama, T.\& Koshiba, M. (2019). Effect of acute aerobic exercise on arterial stiffness and thyroid-stimulating hormone in subclinical hypothyroidism. Heart and vessels. 34, 1309-1316.

Mastorakos, G. Pavlatou, M.(2005). Exercise as a stress model and the interplay between the hypothalamus-pituitary-adrenal and the hypothalamus-pituitarythyroid axes. Hormone and Metabolic Research. 37:577-584.

Şan, G. Biçer, M. Pancar, Z. Özdal, M. (2019). The Effects of Strength Exercises Done With Bosu For 8 Weeks on Balance and Anaerobic Performance. Journal of Socıal and Humanities Sciences Research. 6(47):4327-4334.

Ozan, M. Buzdağlı, Y. Şıktar, E. et al., (2020). The Effect of Protein and Carbohydrate Consumption during 10-Week Strength Training on Maximal Strength and Body Composition. 06/23:2322-3537.

Ozbay, S. Ulupınar, S. Şebin, E. et al. (2020). Acute and Chronic Effects of Aerobic Exercise on Serum Irisin, Adropin, and Cholesterol Levels in the Winter Season: Indoor Training Versus Outdoor Training. Chinese Journal of Physiology, 63(1):21.

Özdal, M. Biçer, M. Pancar, Z. (2019). Effect on an eight-week core strength training on one-leg dynamic balance in male well-trained athletes. Biology of Exercise. 15(1), 125-135.

Özdal, M. (2016). Influence of an eight-week core strength training program on respiratory muscle fatigue following incremental exercise. Isokinetics and Exercise Science. 24(3): 225-230

Ratamess, N.A. (2012). ACSM's Foundations of Strength Training and Conditioning, pp:516: Wolters Kluwer Health/Lippincott Williams \& Wilkins.

Sultan, S.\&Rashed, L. (2009). Effect of Low Calorie Diet and Exercise on Thyroid Hormones and Leptin Levels. Medical Journal of Cairo University. 77(1),33-39.

Teixeira, R.B. Zimmer, A, de Castro, A.L. de Lima-Seolin, B.G. Türck, P. Siqueira, R. Belló-Kleina, A. Singal. P.K. Sander, A.\&da Rosa Araujo, A.S. (2017). Longterm T3 and T4 treatment as an alternative to aerobic exercise training in improving cardiac function post-myocardial infarction. Biomedicine \& Pharmacotherapy. 95, 965-973.

Zarei, M. Zaeemi, M. \& Rashidlamir, A. (2018). Effects of testosterone enanthate treatment in conjunction with resistance training on thyroid hormones and lipid profile in male Wistar rats. Andrologia. 50(2), e12862. 